\title{
EEN VRAAG, DIE REES IN DE PRAKTIJK EN DIE NIET HAD MOGEN RIJZEN
}

\author{
door Prof. T. Keuzenkamp
}

Het tweede lid van artikel 2 van het Reglement van Arbeid van het Nederlands Instituut van Accountants luidt:

„De leden zijn gehouden hun arbeid op zodanige wijze te verrichten, dat deze een deugdelijke grondslag vormt voor hun mededelingen omtrent de uitkomst van die arbeid".

Een lid van het N.I.v.A. is belast met de accountantscontróle ener in Nederland gevestigde naamloze vennootschap, welke ten doel heeft de exploitatie ener cultuuronderneming in Indonesië. Het is de bedoeling dat, indien de betrokken in Nederland gevestigde accountant zich met de te publiceren jaarrekening kan verenigen, hij deze zonder voorbehoud ondertekent.

Hem worden alle gewenste administratieve bescheiden ter beschikking gesteld, zoals begrotingen, doorschriften der in Indonesië gevoerde administratie met alle originele boekingsbescheiden en bewijsstukken, maandelijkse technische rapporten van in het bedrijf werkzame deskundigen, jaarlijkse technische rapporten van buiten het bedrijf staande deskundigen, met opname-rapporten van aanwezige voorraden van deze deskundigen. $\mathrm{Na}$ contrôle en bestudering van al deze papieren stelt de betrokken accountant zich zelf de vraag of hij na deze door hem verrichte contrōle en studie mag zeggen, dat hij zijn arbeid op zodanige wijze heeft verricht, dat deze een deugdelijke grondslag vormt voor zijn mededelingen omtrent de uitkomst van die arbeid. Hij beantwoordt deze vraag bevestigend, ofschoon hij noch een zijner assistenten enige aanraking heeft gehad met het bedrijf in Indonesië; hij ondertekent de jaarrekening zonder voorbehoud.

Er heerst in accountantskringen geen eenstemmigheid over de vraag, of deze accountant juist handelde of niet. Er zijn beroepsgenoten, die de vraag stellen: „Wat had gij dan nog meer willen doen?" Anderen zijn huiverig om het standpunt van deze accountant te delen en stellen: "Indien dit zo mogelijk en goed is, waarom wordt dan diezelfde handelwijze niet toegepast bij in Nederland gevestigde ondernemingen? En waarom eist men dan van examencandidaten, dat zij op een vraag, hoe $z i j$ een begin van uitvoering geven aan een opdracht tot accountantscontrōle ener jaarrekening, niet verzuimen te vermelden, dat zij zich op de hoogte stellen van de gang van zaken in het bedrijf zelf?"

$B$ ij geen dezer beide vragen stelt men het vraagstuk principieel; langs deze weg kunnen wij niet tot de oplossing komen van dit toch werkelijk interessante verschil van mening.

Mijns inziens dient de accountant het volgende te overwegen.

Het verkeer verwacht van de accountant zonder enige twijfel, dat de jaarrekening die hij ondertekent, een juist beeld geeft van het gevoerde beheer. Het oordeel dat hij velt over al of niet juistheid van dit beeld. zal als elk oordeel dat hij velt, moeten zijn een zelfstandig en onpartijdig oordeel, dat gefundeerd is op eigen arbeid. Hoe kan de accountant nu een zelfstandig oordeel uitspreken over de juistheid van het gegeven beeld van het beheer wanneer hij van dit beheer zelf niets heeft gezien? $\mathrm{Hij}_{\mathrm{ij}}$ heeft voor mij gelijkenis met de man die tracht een foto te maken, doch verzuimt het te fotograferen object te belichten. 
Indien hij meent bij het geven van zijn oordeel over de juistheid van het gegeven beeld, zich geheel te kunnen verlaten op rapporten van technische deskundigen, die misschien ter zake in technisch opzicht veel bekwamer zijn dan hijzelf, vergeet hij dat de jaarrekening geen technisch, doch een bedrijfseconomisch en mogelijk in enkele opzichten een juridisch stuk is. Voor het opstellen volgens juiste bedrijfseconomische denkbeelden is hij zelf de man en is contact met dat bedrijf vereist, zol nodig met behulp van een collega. Dit contact wordt niet verkregen door tussen zich zelf en het bedrijf een barricade van papieren op te stapelen om daarachter handtekeningen te stellen. 